\title{
整
}

\section{Die Perfeksionisme: 'n apologetiese en etiese beoordeling}

S.G. Kemp

Departement Bybelkunde en Filosofie

Potchefstroomse Universiteit vir $\mathrm{CHO}$

Vaaldriehoekkampus

VANDERBIJLPARK

E-pos: bybsgk@puknet.puk.ac.za
P.J. de Bruyn

Skool vir Kerkwetenskappe

Potchefstroomse Universiteit vir $\mathrm{CHO}$

POTCHEFSTROOM

E-pos: dekpjdb@puknet.puk.ac.za

\begin{abstract}
Perfectionism: an apologetic and ethical evaluation

For ages the term Perfectionism had only been applied to imply perfect holiness, but was later used to imply perfect health and, since the beginning of the twentieth century, to perfect prosperity. In this article the viewpoints of the proponents of Perfectionism and what they attempt to attain are investigated. Secondly, these viewpoints are tested against Scripture and the Reformational confession. Thirdly, the findings are evaluated in the light of Scripture.
\end{abstract}

\section{Inleiding}

\subsection{Probleemstelling}

Die verskynsel wat in hierdie artikel behandel word, staan bekend as die Perfeksionisme. Dit is die stroming wat leer dat die mens in hierdie lewe op aarde volkome heilig kan wees of ' $n$ vorm van volmaaktheid kan bereik en selfs nie meer sondig nie.

McCauley (1983:3) van die Neo-charismatiese groepe (Rhema Bible Church) maak aanspraak op volmaaktheid in die sin van volmaakte heiligheid van sy kerk op grond van 'n profetiese openbaring wat hy volgens sy eie getuienis sou ontvang het. Hy sê: "We will be a church without spot or blemish". In latere tye het die Perfeksionisme 'n wyer betekenis begin kry: volmaakte heiligheid impliseer volmaakte gesondheid en volmaakte voorspoed (Copeland, 1978:48; Van Zijl, 1984a:2). 
Daarteenoor staan onder andere die uitspraak van gereformeerdes soos Heyns $(1982: 97,100)$ dat "die Christelike lewe een voortdurende, onafgebroke stryd" sal wees - 'n stryd wat in 'n onlosmaaklike verband met die mens se sondige natuur staan waarvan hy nooit, soos die Perfeksionisme graag leer, in hierdie bedeling ontslae kan raak nie. Volgens Van Wyk (1986:8) is die volmaaktheid waartoe die Skrif oproep 'n volmaaktheid in gebrokenheid (vgl. 1 Joh. 1:10; Fil. $3: 12$ ). Bowendien word in die gereformeerde belydenis sedert die sestiende eeu verklaar dat diegene wat tot God bekeer is, God se gebooie nie volkome kan onderhou nie, want "selfs die allerheiligstes het, solank hulle in hierdie lewe is, nog maar 'n klein begin van hierdie gehoorsaamheid ..." (H.K., Sondag 44, vr. 114).

Die vraag is nou: Het die aanhangers van die Perfeksionisme Skriftuurlike gronde om van die gereformeerde belydenis af te wyk of nie? Dit is die probleem wat in hierdie artikel ondersoek word.

\subsection{Aktualiteit en noodsaaklikheid}

Die Perfeksionisme as verskynsel is tans besonder aktueel, veral met die opkoms van die Pentekostalisme en die Charismatiese Beweging wat die draagwydte van die begrip Perfeksionisme uitgedra het na volmaakte gesondheid en volmaakte voorspoed. Dit is tans McCauley en andere se standpunt. Die drie aspekte wat sterk na vore tree en hier behandel word, is die heiligheidsperfeksionisme, die gesondheidsperfeksionisme en die voorspoedperfeksionisme. Die krisis wat die Perfeksionisme vir Christene meebring, veral jongmense wat daarmee gekonfronteer word, maak 'n wetenskaplike besinning daaroor uiters noodsaaklik en aktueel.

\section{Kort historiese oorsig}

Die verskynsel van die Perfeksionisme het reeds in $156 \mathrm{n.C}$. ontstaan by Montanus, die leier van 'n entoesiastiese, ekstatiese en asketiese beweging (Buys, 1995:22; Hommes, s.a.:64; Kelly, 1973:59; Schulze, 1980:4). Daarvandaan loop dit oor die Middeleeuse sektewese en die Anabaptiste via Wesley na die Pentekostalisme en die hedendaagse Charismatiese Beweging. Wesley was die geestelike en intellektuele vader van die moderne Heiligheids- en Pentekostalistiese bewegings (vgl. Kemp, 1992:13-93).

\subsection{Die Neo-Pentekostalistiese of Charismatiese Beweging sedert 1960}

Hoewel die Charismatiese Beweging gegroei het uit en afstam van die Pentekostalisme, moet dit tog as twee verskillende, hoewel verwante, magte beskou word (Spitler, 1976:8). Die verskil kom veral daarin na vore dat die Pente- 
kostaliste selfstandige kerke gestig het, terwyl die meeste charismatici verkies het om in hulle eie kerke te bly (Gause, 1976:109; Jonker, 1981:220). Lidmate van gevestigde kerke het in hulle kerke gebly, maar hulle laat herdoop en die geestesgawes wat in 1 Korintiërs 12:7-11 genoem word, begin beoefen.

Bennett, rektor van die St. Marks Episcopal Church van Nuys in Los Angeles, wat volgens sy eie getuienis met die Heilige Gees gedoop is en die gawe van spreek in tale ontvang het, kan as pionier van hierdie beweging beskou word (Hollenweger, 1973:5; Quebedeaux, 1976:9, 55).

Oor die algemeen is die Neo-Pentekostaliste teologies goed onderlê en nie so biblisisties en emosioneel soos die Pentekostaliste nie (Jonker, 1981:222, 226). Tog is die Neo-Pentekostaliste ook die mening toegedaan dat 'n ervaring soos die doop met die Heilige Gees (GES-rapport, 1979:75) wat bo die verlossing deur die geloof uitgaan, vir die ware Christen noodsaaklik is. Hierdie siening het verskeie ingrypende gevolge:

- die beklemtoning van die ervaring (nuwe openbarings van die Gees) lei tot 'n relativering van die Skrif;

- vanweë hulle siening van die ervaring is hulle uitgangspunt antroposentries en nie teosentries nie;

- dié wat na bewering met die Heilige Gees gedoop is, openbaar 'n sekere vorm van hoogmoed omdat hulle neersien op die ander lidmate en ampsdraers wat dit nog nie ervaar het nie;

- daar is by hulle 'n baie sterk tendens van asketisme;

- hulle probeer om reeds in hierdie bedeling 'n kerk sonder vlek of rimpel daar te stel (Kemp, 1992:75-78);

- hierdie siening kan maklik lei tot 'n Christus-plus-verlossing, Christus plus die religieuse ervaring.

\subsection{Die Nuwe of Neo-charismatiese groepe en kerke sedert 1970}

In teenstelling met die Neo-Pentekostaliste het die Neo-charismatiese groepe kerke gestig soos die Rhema Bible Church (Ray McCauley), Christian City (Theo Wolmarans), Gospel Super Dome (Nicky van der Westhuizen), ensovoorts. Hulle staan ook bekend as aanhangers van die "voorspoedkultus", waarskynlik as gevolg van die "wonderwerke" op stoflike gebied waarop hulle aanspraak maak. Opvallend dat by hulle die man en sy vrou albei pastore is en as president en 
visepresident aan die hoof van die kerke staan sodat die kerke hoofsaaklik om bepaalde persone wentel (Kemp, 1992:78).

Die Rhemakerk het in 1979 onder leiding van McCauley met 13 mense in sy ouerhuis in Randburg begin (Lulckhoff, 1984b:3; Steele, 1986:49). Tans het hulle meer as 40 gemeentes in Suid-Afrika (Janse van Rensburg, 1986:1). Daar is groot bewondering vir McCauley. Hy word deur sy aanhangers met Moses, Josef en Dawid vergelyk en hulle is van oordeel dat hy deur God gestuur is om sy volk te red. Hy word selfs as 'n moderne goddelike profeet beskou. McCauley maak daarop aanspraak dat sy kerk die handelinge van die apostels in die vroeë Christelike kerk navolg. Die doop met die Heilige Gees, die spreek in tale, wondergenesings en ander wonders word deur hulle beoefen (Ronge, 1982:18; Steele, 1986: 167).

\section{Enkele teologiese opvattings}

\subsection{Die kerk is volmaak}

Soos reeds aangedui, maak McCauley (1983:3) aanspraak op volkome heiligheid van sy kerk op grond van 'n profetiese openbaring wat hy volgens sy eie getuienis ontvang het.

\subsection{Waterdoop en doop met die Heillge Gees}

Die waterdoop word alleen bedien aan diegene (volwassenes) wat hulle geloof na 'n nuwe geestelike geboorte kan bely. Daarna ontvang hulle die doop met die Heilige Gees en met vuur, wat gepaard gaan met die spreek in tale as bewys van die ondervinding (Janse van Rensburg, 1986:4-9).

\subsection{Goddeiike genesing deur die geiowige}

Hulle beweer dat goddelike genesing deur die gelowige se gebed en die oplegging van hande moontlik is omdat God die krag daarvoor gee. Trouens, die gelowige kan nie net deur Christus enkele geloofswerke doen nie, maar die ware Christen word uiteindelik Christus self en kan dus dieselfde werke as Christus doen. Omdat die Christen self Christus is, kan hy heers oor die natuurwette wat armoede, teenspoed en siekte veroorsaak (Janse van Rensburg, 1986:17). Terme wat hulle graag gebruik is "positive confession" en "name it and claim it". Hagin (1980:3) beweer dat as jy iets positief in jou hart glo en dit met jou mond sê, dan sal jy dit kry. Volkome gesondheid is die reg van elke gelowige en daarom kan hy dit in die Naam van Jesus opeis (Copeland, 1972:3).

Wolmarans van Christian City het selfs gebedsgenesing deur die pos aangekondig. As 'n kledingstuk van die sieke aan hom gestuur word, sal hy persoonlik sy hande daarop lê en 'n gebed doen. Die sieke moet dan by ontvangs 
van die kledingstuk dit op die liggaam plaas en God vir die genesing prys. Dan sal die sieke ervaar hoe die wannte van God se genesingskrag uit die kledingstuk vloei (Wolmarans, 1987:12).

Indien 'n sieke na 'n mediese dokter gaan, word dit deur die geloofsgenesers as teken van ongeloof beskou.

Emstige kritiek is op hierdie optrede van die geloofsgenesers uitgespreek:

- Tereg is daarop gewys dat hulle probeer om aan God voor te skryf wat om te doen (Ferreira, 1992).

- Hulle maak op 'n eties onaanvaarbare wyse van outosuggestie gebruik wat tot gevolg het dat jy jouself inbeeld dat jy gesond of voorspoedig is terwyl dit in werklikheid nie die geval is nie (Janse van Rensburg, 1986:10).

- Die Bybel word misbruik deur eensydige en ongeldige afleidings te maak om by hulle beskouings in te pas. Teksverse word op die klank af en buite hulle konteks aangehaal (Janse van Rensburg, 1986:43-50).

- Indien 'n persoon nie na 'n gebed van 'n geloofsgeneser gesond word nie, word sy/haar eie ongeloof aangedui as rede daarvoor en so word die persoon in 'n verskriklike geloofskrisis gedompel asof God hom/haar verwerp het (Grobler, 1990).

- Medici wat dikwels die "mislukkings" van die geloofsgenesers moet probeer herstel, skroom nie om die geloofsgenesers van oneerlikheid en uitbuiting te beskuldig nie (Falkson, 1990; Kemp, 1992:82-84).

\subsection{Bybelse voorspoed}

McCauly (aangehaal deur Steele, 1986:50, 122) het van die begin af die sogenaamde Bybelse voorspoed verkondig. Hierdie leer kom daarop neer dat die gelowige alles sal verkry wat hy in die geloof van God opeis, want God wil vir sy kinders net voorspoed skenk. Daarmee word materiële voorspoed, rykdom en genesing bedoel.

'n Ondersoek deur Pauw (1987:20) het getoon dat hierdie geloofsgenesers van skokkende geldinsamelingsmetodes gebruik maak. Van der Westhuizen het, toe hy nog prediker in die Charisma Christensentrum in Roodepoort was, binne drie minute R72 000,00 ingesamel deur onder die dekmantel van godsdiens die mense in die kerk tot so ' $n$ mate emosioneel af te pers dat hulle bykans nie anders kon as om groot hoeveelhede geld te gee nie. By geleentheid het hy selfs lede van sy binnekring so opgesweep dat hulle hulle ringe in die offermandjie gegooi het. Een persoon het getuig dat Van der Westhuizen R500,00 gevra het om vir hom te bid. 
Op soortgelyke wyse is daar ook opgetree deur Wolmarans van Christian City, McCauley van die Rhema Bible Church en Swaggert van die Assemblies of God (Kemp, 1992:87).

"Geld, mag, aansien, verering en selfs aanbidding deur hulle volgelinge en bowenal alleenbeheer oor die finansies is almal kenmerke van die bediening van die twaalf grootste 'geloofsgenesers' in Suid-Afrika" (Lückhoff, 1984a:1).

Om op hierdie maniere geld in te samel en dan te praat van Bybelse voorspoed is, om die minste daarvan te sê, onverantwoord.

\subsection{Samevattend}

Uit die voorgaande is dit duidelik dat die Perfeksionisme by die Charismatiese en Neo-charismatiese Kerke in drie onderafdelings verdeel kan word, naamlik die heiligheidsperfeksionisme, die gesondheidsperfeksionisme en die voorspoedperfeksionisme. Vir die handhawing van hulle standpunte oor elkeen van hierdie drie word daar deur hulle 'n beroep gedoen op uitsprake in die Skrif. In die volgende afdeling sal hulle beroep op die Skrif by elkeen van die drie afdelings krities beoordeel word.

\section{Teties-kritiese beoordeling van die Perfeksioniste se Skrifberoep}

\subsection{Die heiligheidsperfeksionisme}

Die heiligheidsperfeksionisme kom op die volgende neer:

- die gelowige kan vry van sonde en derhalwe in 'n staat van sondeloosheid lewe;

- dit is vir die mens moontlik om aan al God se eise te voldoen;

- geestelike volmaaktheid en volmaakte heiligheid is in die teenswoordige lewe bereikbaar (Kemp, 1992:96).

Die belangrikste Skrifgedeeltes waarop hulle hulle in hierdie verband beroep, is Matteus 5:48 en Filippense 3:12 en 15.

\subsubsection{Matteus 5:48}

\section{Uiteensetting}

Christus sê volgens dié teks in sy bergrede: "Wees julle dan volmaak soos julle hemelse Vader volmaak is". 
Volgens Wesley $(1960: 7,8)$ impliseer hierdie teks dat die gelowige van alle sonde gereinig is en soos die Vader in die hemel volmaak is. Die Shakers het op grond van hierdie teks op volmaaktheid in hierdie lewe aanspraak gemaak (Whitson, 1983:116-118). Finney (1963:101) het op grond van dieselfde teks volkome heiligmaking van die gelowiges verkondig. Dit is hierdie siening wat ook neerslag vind by McCauley (1983:3) in sy uitspraak: "We will be a church without spot or blemish."

\section{Beoordeling}

In genoemde uitspraak van Christus moet veral die woorde volmaak en soos reg verstaan word.

Die woord volmaak het hier nie 'n materiële betekenis nie, maar 'n formele betekenis. As dit 'n materiële betekenis gehad het, sou dit beteken het dat die mens presies dieselfde volmaaktheid moet hê as wat God het, en dit is tog totaal onmoontlik en daarom sinloos. Dit kan eenvoudig net nooit gebeur nie, want dan sal die mense ook gode moet wees - presies soos God. Daarom is die enigste alternatief dat dit ' $n$ formele betekenis moet hê. Dan het dit die betekenis van konsekwent wees en nie halfpad bly staan nie. Binne die konteks waarin dit voorkom, wil Christus met die uitspraak sê: Soos julle Vader in die hemel nie halfpad bly staan in die betoning van sy goedheid nie maar laat reèn op regverdiges en onregverdiges, so moet julle as dissipels ook volmaak, dit wil sê konsekwent wees in julle liefdebetoning en nie halfpad bly staan deur net aan persone waarvan julle hou, liefde te betoon en aan ander, waarvan julle nie hou nie, julle vyande, nie liefde te betoon nie (vgl. Ridderbos, 1965:122, 123). Dit beteken dus dat hulle in ' $n$ bepaalde opsig die volmaaktheid van God moet vertoon sonder om in alles soos God volmaak te wees. 'n Mens sien dit ook in Lukas 6:36: "Wees barmhartig soos julle Vader barmhartig is."

As 'n mens die hele saak in die lig van die woord soos bekyk, kan feitlik dieselfde gesê word as wat hierbo van volmaak gesê is. Dan kom dit daarop neer dat die woord soos nie ontologies verstaan moet word asof die mens wesensgelyk is aan God nie, maar dat dit modaal verstaan moet word wat beteken dat die mens op 'n menslike wyse 'n spesifieke eienskap of deug van God vertoon - in hierdie geval die wyse waarop God liefde betoon (Du Plessis, 1959:171).

In die lig van hierdie uiteensetting is dit duidelik dat daar in Matteus 5:48 geen grond gevind kon word vir die heiligheidsperfeksionisme soos die aanhangers daarvan beweer nie. 


\subsubsection{Filippense 3:12 en 15}

\section{Uiteensetting}

In genoemde tekste skryf Paulus (1953-vertaling): "Nie dat ek dit al verkry het of al volmaak is nie, maar ek jaag daarna of ek dit ook kan gryp omdat ek ook deur Christus gegryp is ... Laat ons almal dan wat volmaak is, so gesind wees; en as julle anders gesind is, sal God dit ook aan julle openbaar".

Volgens die Perfeksioniste praat Paulus hier van twee soorte volmaaktheid: in vers 12 praat hy van die sondelose volmaaktheid wat die gelowige eers in die hemelse heerlikheid sal ontvang; in vers 15 praat hy egter van die teenswoordige volmaaktheid wat beteken dat hy volkome van sy sonde bevry en gereinig is en met die Heilige Gees vervul is. Dit word dan ook as 'n "waaragtige volmaaktheid" beskou (Brockett, 1939:43, 44; Cook, 1963:58, 59).

\section{Beoordeling}

In Filippense 3:12 het die woord volmaak betrekking op die opstanding uit die dood. Teenoor die mense wat meen dat die volmaaktheid hier op aarde bereik kan word, verdedig Paulus die siening dat die volmaaktheid eers in die opstanding uit die dood bereik kan word (Louw \& Nida, 1988:263). Hy beywer hom ook om dit te verkry.

In Filippense 3:15 dui die woord volmaak egter 'n relatiewe volmaaktheid aan en nie 'n absolute volmaaktheid nie (Müller, 1977:68). Daarmee wil Paulus sê dat die gelowiges in beginsel reeds volmaak is, maar die volmaaktheid word in hierdie lewe nie ten volle gerealiseer nie. Die volmaaktheid rus egter nie in die mens self met sy godsdienstige prestasies nie maar enkel en alleen in die verlossingswerk van Jesus Christus (Du Plessis, 1959:196).

Net soos 'n klein kindjie 'n volmaakte menslike wese is maar nog nie in sy ontwikkeling volmaak is nie, so is die gelowige in en deur Christus volmaak "in al sy dele" maar nog nie volmaak in al die stadiums van die ontwikkeling van die geloof nie (Greijdanus, 1962:217; Kuyper, 1927:592-597).

Die gelowige besit prinsipieel in Christus die volmaaktheid, maar probeer elke dag om dit nog meer te verwesenlik - om al hoe meer te word wat hy reeds in Christus is. Die volheid daarvan sal egter eers na hierdie lewe bereik word. So gesien, bied hierdie uitsprake van Paulus ook geen steun aan die heiligheidsperfeksionisme nie.

Dit is duidelik dat die Skrifberoep op Matteus 5:48 en Filippense 3:12 en 15 ten gunste van ' $n$ heiligheidsperfeksionisme nie geldig is nie. Boonop is daar duidelike getuienisse uit die Skrif dat die kerk op aarde nooit volmaak sal wees nie. In Jesus se gelykenisse van die onkruid tussen die koring (Matt. 13:24-30 en 
36-43) en die goeie en slegte visse (Matt. 13:47-50) en ook in die uitspraak van Johannes die Doper (Matt. 3:12) word duidelik geleer dat die sigbare kerk uit goeies en slegtes bestaan en so sal voortbestaan tot by die oordeelsdag.

Die heiligheid van die kerk bestaan daarin dat dit deur Christus geheilig is Daarom kan Paulus die kerk in Korinte, ondanks die ernstige sondes wat daarin aangetref is, tog "geheiligdes" en "geroepe heiliges" noem (1 Kor. 1:2, 1953vertaling). Die kerk het natuurlik die roeping om steeds meer te word wat hy reeds in Christus is.

\subsection{Gesondheidsperfeksionisme}

Volgens die aanhangers van hierdie siening behoort ware gelowiges perfekte gesondheid te hê bloot omdat hulle ware gelowiges is (Van Zijl, 1984b:2).

Die volgende is enkele standpunte of uitsprake van aanhangers van die gesondheidsperfeksionisme:

- Sonde as oortreding van die wet bring siekte. Christus het ons volgens Galasièrs $3: 13-14,29$ van die vloek van die wet verlos. Daarom behoort gelowiges altyd gesond te wees (Hagin, 1978:3, 14, 15, 26).

- Gesondheid kom van God. God wil dat almal genees moet word. Daarom mag nooit gebid word dat God se wil moet geskied nie, want dit is 'n teken van ongeloof en twyfel aan die vermoë van God. Die gelowige mag volkome genesing van God opeis (Copeland, 1981:7; McCauley, soos aangehaal deur Steele, 1986:138-143).

- Christene mag nooit siek wees nie omdat dit altyd God se wil is dat hulle volmaak gesond moet wees (Osborn, 1950:13, 14).

- Genesing vind plaas deur 'n direkte goddelike ingryping op grond van die gebed van die gelowige. God en 'n dokter werk nie saam nie (Müller, 1980:7 se beoordeling van geloofsgenesers).

- As 'n gelowige Jesus as Geneesheer aanneem, kan hy oombliklik in perfekte gesondheid lewe (Van Zijl, 1984b:9-11; 1988:12, 13).

- Jongmense het nie nodig om te sterf nie omdat God, volgens Eksodus 23:25, 26 en Psalm 91:16 siekte van hulle af weghou en hulle 'n lang lewe belowe (Copeland, 1981:5).

- As daar vir 'n sieke gebid word en hy word nie gesond nie, is dit vanweë gebrek aan geloof of vanweë sonde by die siek persoon (Falkson, 1990; 
Grobler, 1990; McCauley soos angehaal deur Steele, 1986:138-143). As hy gesond word, kom die eer egter in die reêl die geloofsgeneser toe.

- Alle siekte kom van die duiwel (Hagin, 1978:17, 19; Van Zijl, 1981:21; 1983:7,9).

- Iemand met 'n siek liggaam kan nie diensbaar wees aan God nie (Lindsay, 1974:4, 5).

Die Skrifgedeeltes waarop die gesondheidsperfeksioniste hulle in hierdie verband beroep, is veral Eksodus 15:26 en Matteus 8:2-3

\subsubsection{Eksodus 15:26}

\section{Uiteensetting}

Volgens hierdie teks het die Here deur Moses aan Israel gesê: "Julle moet goed luister na wat Ek, die Here julle God sê! Julle moet doen wat reg is in my oê, gehoor gee aan my gebooie en alles doen wat Ek vir julle voorskryf. Dan sal Ek geeneen van die siektes waarmee Ek Egipte getref het, oor julle bring nie, want dit is $E k$, die Here, wat julle gesond hou."

Vir die geloofsgenesers is ' $n$ mens se genesing en gesondheid afhanklik van sy gehoorsaamheid aan en geloof in God. Die volk van God wat Hom gehoorsaam dien, sou volgens hulle nie aan enige siekte blootgestel word nie, want God genees altyd (Kemp, 1992:122).

Volgens Simpson (1915:11) is Eksodus 15:26 die vroegste belofte van genesing. Siekte is nie bedoel vir die volk van God nie, maar Hy bring dit wel oor die Egiptenare. In hierdie teks het God Homself as die groot Geneser geopenbaar. Genesing was egter nie 'n outomatiese seën nie, maar was afhanklik van die gehoorsaamheid aan God se Woord. So lank as wat die volk die verbond onderhou het, het geen kwaal oor hulle gekom nie. Sodra hulle die Woord van God verontagsaam het, was hulle weer aan siekte blootgestel (Copeland, 1972:15, 16; Van Zijl, 1984b:29, 34). Omdat die volk God se Woord aanvaar het, was daar volgens Psalm 105:37 nie een sieke onder die ongeveer drie miljoen Israeliete wat Egipte verlaat het nie (Osborn, 1950:12, 13). God het 'n genesingsverbond met sy volk aangegaan omdat $\mathrm{Hy}$ weet dat iemand met 'n siek liggaam nie vir Hom diensbaar kan wees nie (Lindsay, 1974:4, 5). Diegene wat God se Woord aanvaar, sal genees word en verder sonder siekte lank op die aarde bly woon. God se Woord is die medisyne vir die lewe en gesondheid van die mens (Copeland, 1981:14-18). 


\section{Beoordeling}

Die gesondheidsperfeksioniste sê dat siekte gesien moet word as 'n straf van God op ' $n$ mens se sonde. As 'n mens dus nie sonde doen nie, sal jy altyd gesond wees. In die lig van Job 1, 2, 42 en Johannes 9:1-3 is dit duidelik dat die siening nie sonder meer reg is nie. Die siekte van Job $(1: 8,22 ; 2: 10 \mathrm{~b})$ en die blindheid van die blindgeborene (Joh. 9:3) kon beslis nie teruggevoer word na een of ander sonde by hulle nie.

Eksodus 15:26 sê ook nie dat die Israeliete nooit sal siek word nie, maar dat die Here hulle nie met die spesifieke siektes sal tref waarmee $\mathrm{Hy}$ die Egiptenaars voor die uittog getref het nie.

Dit is moontlik dat daar geen siekes was tydens Israel se uittog uit Egipte nie. Hoe Van Zijl (1988:22) dit egter uit Psalm 105:37 kan aflei, is onbegryplik, want in die betrokke teks is daar geen sprake van siekte nie. Indien dit wel so was dat daar op daardie stadium geen siekes onder Israel was nie, moet 'n mens dit sien as deel van die groot wonder van God toe Hy Israel uit Egipte uitgelei het. Later toe hulle in Kanaän gevestig was en sake "genormaliseer" was, het siekte heel dikwels voorgekom, ook by mense wat hulle nie uitdruklik skuldig gemaak het aan een of ander spesifieke sonde nie. 'n Mens dink in hierdie verband byvoorbeeld aan die siekte van Hiskia (Jes. 38:1-8), dié van Abia, die seun van Jerobeam (I Kon. 14:1), dié van die seuntjie van die weduwee van Sarfat (1 Kon. 17:17), dié van Elisa wat emstig siek word en op sterwe lê (2 Kon. 13:14) en dié van die kind van Batseba en Dawid (2 Sam. 12:15; vgl. Kemp, 1992:126-128).

Die groot probleem met die gesondheidsperfeksioniste is dat hulle die Bybel biblisisties hanteer. Hulle neem sekere losstaande tekste, maak dit los uit hulle direkte verband en uit die verband van die Skrif as geheel en maak dan eensydige afleidings daaruit. Dit is ook die geval met Eksodus 15:26 en daarom kan hulle afleidings nie as geldig beskou word nie.

\subsubsection{Matteus 8:2-3}

\section{Uiteensetting}

In hierdie Skrifgedeelte staan die volgende: "'n Melaatse man kom kniel toe voor Hom en sê: 'Here, as U wil kan U my gesond maak.' Toe steek Jesus sy hand uit, raak hom aan en sê: 'Ek wil. Word gesond!' En sy melaatsheid was onmiddellik weg."

Vir die gesondheidsperfeksioniste is dit 'n baie belangrike Skrifgedeelte. Volgens Van Zijl (1983:2) het Christus op daardie oomblik met die woorde "Ek wil. Word gesond!" sy wil vir tyd en ewigheid uitgespreek. Howton $(1909: 41,46)$ sê op grond van hierdie uitspraak van Jesus dat dit God se wil is om aan al sy kinders volmaakte gesondheid te gee. Vir hom is dit ondenkbaar dat die melaatse Jesus 
sou vra om net sy siel te red en nie ook om hom van die melaatsheid van die liggaam te verlos nie. In hierdie verband stel McCauley (in Steele, 1986:136) dit kategories dat dit God se wil is dat almal genees moet word. Van Zijl (1983:1, 2; $1988: 7,8)$ beroep hom vir hierdie siening verder daarop dat Jesaja $(53: 4,5)$, Matteus (8:17) en Petrus (1 Pet. 2:24) saamstem dat Jesus die krankhede van die mens op Hom geneem het en hulle siekte gedra het. Daarom is dit sy wil dat hulle gesond moet wees. Volgens Copeland $(1972: 37,38)$ is Satan die bron van siekte en daarom is dit teen die wil van God dat sy kinders siek moet wees.

\section{Beoordeling}

In hierdie verband moet op die volgende gelet word:

- Dit is nie duidelik waarom hulle soveel nadruk spesifiek op hierdie wonder lê nie. Jesus het tog baie ander wonders gedoen waarna hulle ook kan verwys. Miskien moet die antwoord daarin gesoek word dat die bewoording van hierdie wonder sodanig is dat hulle dit makliker as ander in hulle siening kan inforseer.

- Die wonders van Jesus het 'n spesifieke betekenis gehad: dit moes dien as bevestiging dat Hy die ware Messias, die Seun van God is sodat die mense in Hom kon glo. Dit is duidelik dat die geloofsgenesers hierdie betekenis van Christus se wonders nie verstaan nie as hulle vir hulleself die reg toeeien om dieselfde te kan doen wat Jesus tydens sy omwandeling op aarde gedoen het (Keulers, 1950:110; Louw, 1977:97).

- Die genesing van Jesus het altyd gerealiseer - ook in gevalle waar persone klaarblyklik slegs 'n wondergeloof gehad het en nie 'n saligmakende geloof nie (Luk. 17:11-19). Die "genesings" van die geloofsgenesers realiseer nie altyd nie en dan sê hulle dat die ongeloof of sonde van die sieke die oorsaak daarvan is.

- Die genesings van Jesus het onmiddellik gerealiseer, terwyl die geloofsgenesers sê dat hulle genesings deur 'n proses gerealiseer word (Copeland, 1987; Farah, s.a.:22).

- Dit is nie waar dat alle gelowiges van hulle siekte bevry is nie. Paulus se doring in die vlees is ondanks sy gebede nie van hom weggeneem nie ( 2 Kor. 12:7-10), en in Galasiërs 4:13 maak hy melding van sy siekte. Hy laat Trofimus siek in Milete agter ( 2 Tim. 4:20). Timoteus het self ook gesukkel met herhaalde ongesteldhede en Paulus moedig hom aan om 'n bietjie wyn met die oog daarop te gebruik (1 Tim. 5:23).

- Die geloofsgenesers is uiters inkonsekwent. Christus en die apostels het immers nie net siekes genees nie maar ook dooies opgewek (Joh. 11:33-44); 
Hand 9:36-41). Waarom wek die geloofsgenesers nie ook dooies op nie? As siekte vir God nie aanvaarbaar is nie, sou die dood miskien vir Hom aanvaarbaar wees? Waarom maak hulle nie ook storms stil nie?

Ook hierdie poging van die gesondheidsperfeksioniste om hulle siening en optrede te regverdig laat veel te wense oor omdat hulle die Bybel op biblisistiese wyse misbruik en nie erns maak met die konteks en met 'n studie van die hele Woord van God nie.

Die tragedie in hierdie verband is dat die gesondheidsperfeksioniste bykans met moord wegkom (Falkson, 1990). Want wat gebeur? As 'n sieke na 'n gebed van een van hierdie persone nie gesond word nie, word die rede daarvoor op die sieke self geplaas: daar is nog sondes wat nie bely is nie of daar is 'n gebrekkige geloof by hom of haar. As die sieke egter wel gesond word, kry die geloofsgeneser die eer daarvoor (Grobler, 1990; Ferreira, 1992). Op dié wyse kan die geloofsgeneser verwoesting aanrig in die lewe van 'n mens, want pasiënte wat hulle kruis voorheen in die geloof gedra het, word - as hulle nie genees is nie - weggestuur met die verwyt dat hulle siek is omdat hulle nog te sondig of te ongelowig is (Grobler, 1990).

\subsection{Voorspoedperfeksionisme}

Volgens die voorspoedteologie wil God sonder meer voorspoed aan sy kinders skenk.

Copeland (1978:6-14) beweer dat God van die skepping af finansiële voorspoed voorsien vir diegene wat sy Woord gehoorsaam. Sy verwys na die rykdom van Abraham en Jakob en hulle nakomelinge wat hulle op grond van die verbond met God van Hom verkry het. Die nuwe verbond wat deur die bloed van Christus bevestig is, verseker dat al die gelowiges die beloftes van Abraham ontvang. So bring die Woord aan die lig dat gebrek en armoede nie God se wil vir die gehoorsames is nie. Indien iemand armoede aanvaar, word die instelling van die verbond verwerp, want Satan is die outeur van armoede (Hagin, 1978:3-13). Almal wat aan die verbond getrou bly, ervaar buitengewone finansiele voorspoed. Christene wat die belofte van stoflike voorspoed en rykdom in die geloof aanvaar, moet as bewys daarvan 'n tiende van hulle inkomste aan die kerk (Rhema) gee (Janse van Rensburg, 1986:18).

Hulle siening kom dus kortliks daarop neer: glo in God en gehoorsaam sy gebooie en jy sal baie ryk word en 'n voorspoedige lewe hê.

Die idee van die voorspoedgodsdiens is tipies van die twintigste eeu. In die geskiedenis van die kerk is daar nêrens in die vorige eeue enige verwysing daama gevind nie (Kemp, 1992:138). 
Van die belangrikste Skrifuitsprake waarop die voorspoedperfeksioniste hulle siening grond, is Deuteronomium 8:17-18 en Markus 11:22-24.

\subsubsection{Deuteronomium 8:17-18}

\section{Uiteensetting}

In aansluiting by vers 11 word in hierdie gedeelte aan Israel gesê:

Neem jou dan in ag dat jy die Here jou God nie vergeet nie .. en jy in jou hart dink: My krag en die sterkte van my hand het vir my hierdie rykdom verwerwe. Maar dink aan die Here jou God, dat dit Hy is wat jou krag gee om rykdom te venwerwe, dat $\mathrm{Hy}$ sy verbond $\mathrm{kan}$ bevestig wat $\mathrm{Hy}$ aan jou vaders met 'n eed beloof het, soos dit vandag is (1953-vertaling).

Op grond van hierdie uitspraak sê Copeland (1978:16) en Hagin (1978:8) dat God aan verbondsmense krag gee om ryk te word. Voorspoed, selfs rykdom, is nodig om die verbond te vestig. Om God in staat te stel om sy belofte aan Abraham gestand te doen, moet Hy toegelaat word (sic) om Abraham se nakomelinge voorspoedig te maak, asof Hy vandag die belofte gemaak het. God se eerste belofte aan Abraham was dat Hy hom ryk sou maak

Abraham se seën is nie net bedoel vir sy fisiese afstammelinge nie, maar volgens Galasiërs 3:14, 19 vir alle Christene. Dit impliseer dat God elke gelowige ryk wil maak. Daarom moet gelowiges die voordele gebruik wat hulle in Christus het (Hagin, 1978:8, 10)

McCauley (in Steele, 1986:12) beskuldig "die kerk" van valse beskeidenheid ten opsigte van geld aangesien die kerk armoede as 'n teken van geestelikheid verheerlik.

Om materiële voorspoed te geniet moet jy God liefhê en sy gebooie gehoorsaam. As jy jou oë op God se Woord hou, sal jy volgens Spreuke 4:20-22 en 7:2 voorspoedig wees (Copeland, 1978:27).

\section{Beoordeling}

Die voorspoedteoloë verstaan glad nie die strekking van die betrokke hoofstuk nie en derhalwe ook nie vers 17 en 18 nie. Die doel van hierdie hoofstuk is nie om aan die volk te sê dat hulle God moet gehoorsaam sodat hulle ryk kan word soos die voorspoedteoloë beweer nie. In hierdie hoofstuk word die volk gewaarsku om, wanneer hulle voorspoed ervaar, God nie te vergeet en te dink dat hulle die rykdom uit eie vermoe bekom het nie. Vers 17 en 18 is dan ook nie 'n aanmoediging om die voorspoedgeloof aan te hang nie, maar is juis 'n waarskuwing aan die adres van die volk om nooit te vergeet hoe diep hulle van God afhanklik is nie (Kemp, 1992:142; Van Rooy, 1977:248, 249). 
Vir die ware gelowige is voorspoed genade sonder verdienste; vir die voorspoedteologie is dit net andersom.

In vers 18 is daar sprake van God se verbond. En dit is nou juis die kenmerkende van die verbond van God dat Hy daarvolgens eers gee en dan eis. Maar die voorspoedteoloë keer dit net om. Verder is die hele gedagte dat slegs rykes - en nie armes nie - besondere begenadigdes van die Here is, in die lig van Christus se brief aan Smirna (Op. 2: 8-11) van alle waarheid ontbloot.

Die verwysing van Copeland (1978:27) na Spreuke 4:20-22 en 7:2 is ook heeltemal irrelevant.

Deuteronomium 8:17-18 bied dus geen grond vir die siening van die voorspoedsteoloë nie.

\subsubsection{Markus 11:22-24}

\section{Uiteensetting}

Jesus antwoord en sê vir hulle: julle moet geloof in God hê Want, voorwaar Ek sê vir julle dat elkeen wat vir hierdie berg sê: Hef jou op en werp jou in die see - en nie in sy hart twyfel nie, maar glo dat wat hy sê, sal gebeur - hy sal verkry net wat hy sê. Daarom sê Ek vir julle: Alles wat julle in die gebed vra, glo dat julle dit sal ontvang, en julle sal dit verkry.

Volgens die voorspoedteoloe is die berg waarvan hier sprake is 'n berg van moeilikhede, onder andere finansiële nood, siekte en allerlei hindernisse in die mens se lewe. Jy moet nie met God daaroor praat nie, maar jy moet die hindemis soos finansiele nood self in die Naam van Christus aanspreek en aansê om uit jou lewe pad te gee, want God gee volgens Jakobus 4:7 aan jou die gesag om dit te doen (Copeland, 1978:77, 78).

Copeland $(1978: 48,49,96)$ sê verder dat die beloftes van materiële voorspoed en rykdom eenvoudig in die geloof aanvaar en dan opgeëis moet word. As jy dus geld wil hê, moet jy dit net in jou hart glo en met jou mond dit uitspreek.

Omdat Cliristus in die plek van die gelowige arm geword het om hom ryk te maak ( 2 Kor. 8:9), is dit deel van die seêninge wat God aan die gelowige gee, naamlik dat hy ryk kan wees. Hierdie rykdom moet net met geloof opgeëis word (Hagin, 1978:4, 5; Van Zijl, 1984a:2, 3).

\section{Beoordeling}

Binne die konteks waarin dit voorkom, het die betrokke Skrifgedeelte niks te doen met die verkryging van voorspoed en besittings nie. Dit gaan oor die geloof en die krag daarvan. Bowendien praat Christus hier nie van 'n figuuslike berg van 
finansiële nood of iets dergeliks nie, maar van 'n letterlike berg: die Olyfberg (Kemp, 1992:148, 149).

Wat hier gesê word, is primêr op die dissipels (apostels) van toepassing. Christus het hulle met wondermag beklee ( 2 Kor. 12:12) met die oog op die verkondiging van die evangelie aan die begin van die vestiging van die kerk. Dit geld nie per se vir alle gelowiges soos die voorspoedteoloe graag wil glo nie. In die siening van die voorspoedteoloë word die unieke karakter van die apostels misken. Hulle wonders was tekens om die Woord te bevestig. Toe die Woordopenbaring afgesluit is, het die wonderteken-openbaring opgehou. Dit beteken nie dat God nie vandag meer wonders kan doen nie, maar dit beteken wel dat daar nie in die huidige bedeling ' $n$ mens is wat wonders kan doen soos die teoloë van die Charismatiese kerke beweer nie (vgl. Chantry, 1976:8, 9, 17-21, 30-37)

Waarskynlik moet hierdie uitspraak om die berg in die see te werp, binne die konteks van die toekomstige taak van die dissipels as 'n hiperbool of masjaal verstaan word waarmee Christus wil sê dat niks wat in ooreenstemming met God se wil is vir die dissipels onmoontlik sal wees nie (Carrington, 1960:242, 243).

Een ding is egter baie duidelik en dit is dat "geloof" waarmee 'n mens oor God wil beskik en Hom tot eie finansiële voordeel wil manipuleer, die naam geloof nie werd is nie, maar veel eerder in die rigting van magie of towery neig (Van Leeuwen, 1964:144, 145). Geloof is beslis nie 'n manipuleringsmiddel nie, maar vra juis die mens om volgens God se wil op te tree.

Die beroep op die uitspraak van Christus in Markus 11:22-24 om te dien as motivering vir die voorspoedteologie het dus ook geen grond nie. Trouens, Christus sê uitdruklik aan sy dissipels as verteenwoordigers van die kerk: "In die wêreld sal julle dit moeilik hê; maar hou moed: Ek het die wêreld klaar oorwin" (Joh. 16:33). Daarby kan groot geestelike rykdom in Christus gevind word by mense wat op stoflike gebied baie arm is (Op. 2:8-11).

Ook hier kry 'n mens met 'n groot tragedie te doen, en dit is dat hierdie voorspoedperfeksionisme daartoe gelei het dat dit veral die leiers en voorgangers in kerke is wat op die ou end skatryk geword het omdat hulle van onaanvaarbare geldmaakmetodes gebruik maak. In werklikheid het hulle mense in die Naam van Christus emosioneel en andersins opsweep tot hulle, die voorgangers, se voordeel (Lückhoff, 1984a:2; Pauw, 1987:20; Joubert, 1988a:6; 1988b:9). Op dié wyse kan groot en luukse kerkgeboue en gebouekomplekse opgerig en baie gou afbetaal word - iets wat die status van die voorganger vanselfsprekend buitengewoon verhoog. Dat talle mense op dié wyse in baie groot finansiële probleme gedompel word, word gerieflikheidshalwe nie genoem nie (Lückhoff, 1984a:2; Pauw, 1987:22). 


\section{Gevolgtrekking}

Die leer en optrede van die Neo-charismatiese kerke soos dit tot openbaring kom in die heiligheidsperfeksionisme, die gesondheidsperfeksionisme en die voorspoedperfeksionisme is op dwalings gegrond, is in stryd met Skrif en belydenis en maak gebruik van praktyke wat uit Christelike oogpunt eties onaanvaarbaar is (Janse van Rensburg, 1983:7, 11; 1986:43-50).

Diè gevolgtrekking word bevestig deur Bakker, voorheen een van die groot voorstanders van die voorspoedgodsdiens. Bakker is in 1989 gevangenisstraf van 45 jaar opgelê weens bedrog. Hy is na vyf jaar ontslaan en nou verkondig hy aan gehore dat dié godsdiens wat hy voorheen aangehang het, 'n leuen en ' $n$ misleiding van die Satan is. By die Azusa '96 kongres in Tulsa, Oklahoma het hy verklaar: "We have taken Scripture out of context and have built our own doctrine. We have another gospel and another Jesus and another spirit being preached ... and the church is going to end up in hell" (Anon, 1996:8).

Die groot fout van die Perfeksioniste is daarin geleè dat hulle in 'n gebroke werklikheid 'n volmaakte heilige kerk wil hê. Baie van die groepe mislei mense in so 'n mate dat sommige gelowiges verward raak en hulle rug op God draai en geheel en al afvallig raak.

\section{Bibliografie}

ANON 1996. Former P.T.L. leader Jim Bakker rejects 'prosperity gospel'. Christian Courier, 52(2503):8.

BROCKETT, HE. 1939? Vrymaking van sonde in die Skrif. In Afrikaans vertaal deur T. Kriel Johannesburg : CUM.

BUYS, P W. 1995. Die charismatiese beweging - ons onbetaalde rekening? Die Kerkblad, 98 (2961):22-24, Apr. 5.

CARRINGTON, P 1960. According to Mark Cambridge : University Press.

CHANTRY, W.J. 1976. Signs of the apostles Edinburgh : Banner of Truth Trust.

COOK, T. 1963. New Testament holiness. 16th ed London : Epworth Press.

COPELAND, G. 1972. God's will for your healing. Fort Worth, Texas : Copeland Ministries.

COPELAND, G. 1978. God's will is prosperity. Tulsa, Oklahoma : Harrison House.

COPELAND, G 1981. And Jesus healed them all. Fort Worth, Texas : Copeland Ministries.

COPELAND, K. 1987. Genesingsbediening tydens erediens van die Rhemakerk, 22 November 1987. Randburg. (Kassetopname in besit van outeur Kemp.)

DU PLESSIS, P J 1959 Teleios: the idea of perfection in the New Testament Kampen : Kok

FALKSON, H 1990. Mondelinge mededeling aan outeur Kemp. Pretoria (Kassetopname in besit van outeurs.)

FARAH, C. Jr. s.a. From the pinnacle of the temple: faith or presumption? Plainfield : Logos International.

FERREIRA, G. 1992. Mondelinge mededeling aan outeur Kemp. Meyerton. (Kassetopname in besit van outeurs.)

FINNEY, C.G. 1963 Attributes of love a section from lectures on systematic theology Minneapolis : Bethany Fellowship. 
GAUSE, R.H. 1976. Issues in Pentecostalism. (In Spittler, R P., ed Perspectives on the New Pentecostalism. Grand Rapids, Michigan : Baker Book House. p 106-116.)

GEREFORMEERDE EKUMENIESE SINODE 1979. Holy Spirit Baptism (In Gereformeerde Kerk in Suid-Afrika Agenda van die veertigste sinodale vergadering van die Gereformeerde Kerk in Suid-Afrika te Potchefstroom 10 Januarie.) Potchefstroom : Administratiewe Buro.

GES-RAPPORT

$K y k$

GEREFORMEERDE EKUMENIESE SINODE-RAPPORT

GREIJDANUS, S. 1962. De brieven van die apostel Paulus aan de Efeziërs en de Filippenzen. Kampen : Kok.

GROBLER, C. 1990. Mondelinge mededeling aan outeur Kemp Johannesburg. (Kassetopname in besit van outeur.)

HAGIN, K.E. 1978 Redeemed from poverty, sickness, death. Tulsa, Oklahoma : Faith Library

HAGIN, K.E. 1980 In Him. Tulsa, Oklahoma : Faith Library.

HEYNS, J A. 1982. Teologiese etiek. Pretoria : NG Kerkboekhandel.

HOLLENWEGER, W.J. 1973. The Pentecostals. Minneapolis : Augsburg Publishing House.

HOMMES, N.J. s.a. De vroeg-Katholieke kerk. (In Grosheide, F.W., Den Hartogh, G.M, Honders, H.J., Van Itterzon, G.P. \& Nauta, D. reds. Geschiedenis der kerk. Deel 1. Kampen : Kok p. 46-109.)

HOWTON, R. 1909. Divine healing and demon possession. London : Ward Lock.

JANSE VAN RENSBURG, J. 1983. Vraagteken oor die Rhemakerk en neerval in die Gees. Die Kerkbode, 135(7):6, 7, 11, Aug. 17

JANSE VAN RENSBURG, J. 1986. Rhema: voorspoed of versinsel Pretoria : NG Kerkboekhandel.

JONKER, W D. 1981. Die Gees van Christus. Pretoria : NG Kerkboekhandel

JOUBERT, F. 1988a. Swaggart erken sondes op TV Beeld. 6, Feb. 23

JOUBERT, F. 1988b. Prostituut-skande: Swaggart 'behandel'. Beeld: 9, Feb. 24

KELLY, J.N.D. 1973. Early Christian doctrines. London : Black.

KEMP, S.G. 1992. Die Perfeksionisme: 'n apologetiese en etiese studie. Potchefstroom : PU vir CHO. (Ph.D -proefskrif.)

KEULERS, J. 1950. Het Evangelie volgens Mattheüs. Roermond : Romen

KUYPER, A. 1927. Het werk van den Heiligen Geest Kampen : Kok.

LINDSAY, G. 1974. Thirty Bible reasons why Christ heals today. Dallas, Texas : Christ for the Nations

LOUW, J.P. 1977. The structure of Mt. 8:1-9:35. Neotestamentica, 11:91-97

LOUW, J.P \& NIDA, E.A. 1988. Greek-English lexicon of the New Testament based on semantic domains. Volume 1. New York : United Bible Societies.

LUCKHOFF, A 1984a. Geloofsgenesing: 'Pastore' soek só geld en mag. Rapport. 1-2, Nov. 25

LÜCKHOFF, A. 1984b. Die kerke rol in die geld. Rapport. 3, Nov. 18.

MCCAULEY, R 1983. The move of the Holy Spirit. Rhema, our God's Reign: 3, Jun.-Jul

MÜLLER, J.J. 1977. Die brief aan die Filippense en die brief aan Filemon Kaapstad : NG Kerk-Uitgewers.

MULLER, J J. 1980. Geloofgenesing. Kaapstad : NG Kerk-Uitgewers.

OSBORN, T.L. 1950. Healing the sick and casting out devils. Tulsa, Oklahoma : Osborn.

PAUW, J. 1987. Geld stroom na nuwe kerke: 'oues' kwyn dood. Huisgenoot: 20-22, Okt 1

QUEBEDEAUX, R. 1976. The new charismatics New York : Doubleday

RIDDERBOS, H.N. 1965. Het Evangelie naar Mattheus. Eerste Deel Kampen : Kok 
RONGE, B. 1982 A ticket to heaven? The Star: 18, Dec. 3.

SCHULZE, L.F. 1980. Die hand in eie boesem (2): 'n populêre medisyne. Die Kerkblad, 82(2536): 4, Feb. 13.

SIMPSON, A.B. 1915. The gospel of healing. Harrisburg, Pennsylvania : Christian Publications.

SPITTLER, R.P. 1976. Preface. (In Spittler, R P., ed. Perspectives on the New Pentecostalism. Grand Rapids, Michigan : Baker Book House. p. 7-10.)

STEELE, R. 1986. Destined to win: a biography, Ray McCauley. Boksburg, Johannesburg Conquest Publishing

VAN LEEUWEN, J.A.C. 1964. Het Evangelie naar Markus. Kampen : Kok

VAN ROOY, H.F. 1977. 'n Vergelyking van die struktuur van die buite-Bybelse staatsverdrae: met besondere aandag aan die Sefire-verdrae met die struktuur van Deuteronomium. Potchefstroom : PU vir CHO. (D.Litt.-proefskrif.)

VAN WYK, J.H. 1986. Inleiding tot die Pinksterteologie. Potchefstroom : PU vir CHO. (In Van der Walt, B.J. red. Onderskeiding van die geeste. Wetenskaplike bydraes van die PU vir $\mathrm{CHO}$, Instituut vir Reformatoriese Studie. Reeks F3: Versamelwerke, no. 26. p. 1-12.)

VAN ZIJ, J. 1981. Bybelse antwoorde oor genesing. Stanger : Geloof in die WoordBedieninge.

VAN ZIJ, J. 1983. God wil jou genees. Stanger : Geloof in die Woord-Bedieninge.

VAN ZIJL, J 1984a Geloofsbrood vir die lente. Stanger : Geloof in die Woord-Bedieninge.

VAN ZIJL, J. 1984b. Waarom sommige nie genees word nie Stanger : Geloof in die WoordBedieninge.

VAN ZIJL, J. 1988. Die Nagmaal en genesing. Stanger : Geloof in die Woord-Bedieninge.

WESLEY, J. 1960. A plain account of Christian perfection. London : Epworth Press.

WHITSON, R E. 1983. The Shakers. London : SPCK.

WOLMARANS, T. 1987. Do you need healing? Christian City News. 12, Dec 
